Linguistik Terapan 16 (3) (2019): 518 - 526

Jurnal Linguistik Terapan Pascasarjana

Available online

http://jurnal.unimed.ac.id/2019/index.php/JLT-Unimed

\title{
THE REALIZATION OF TEACHERS' LANGUAGE STYLE WITH REFERENCE TO SEX DIFFERENCE IN TEACHING ENGLISH
}

Megawati Sinaga

Sumarsih

Rahmad Husein

English Applied Linguistics Program

Postgraduate Program - Universitas Negeri Medan

Diterima September 2019; Disetujui Oktober 2019; Dipublikasikan Desember 2019

\section{ABSTRACT}

The Objectives of this paper are to describe the realization of language styles used by male and female teacher and the reasons of the using those language styles. The subjects were the teachers of SMP Negeri Pancur batu, they were four English teachers, consits of two male teachers and two female teachers. It was qualitative explanative research designs. The researcher observed the teachers while teaching in order to get the teachers language styles taking place during their teaching in the classroom related to the theory of Tannen, who divides the way of communication into six categories; pairs a contrasting use of language by males and females, they are: status versus support, independence versus intimacy, advice versus understanding, information versus feeling, orders versus proposal and conflict versus compromise.

.The results of the data analysis showed that the. The language styles of the male and female teacher were different in the way of communication. The realization of language styles by the teachers' way of speaking mostly occur in male teachers' is orders which is 13 utterances (38.2\%), then followed by advice which is 11 utterances $(32.4 \%)$, then continued by information 6 utterences $(20,6 \%)$ and then conflict 2 utterances $(5,9 \%)$ and the last is status 1 utterances $(2.9 \%)$. Female teachers' way in communication was mostly realized by orders which is 10 utterances $(29.4 \%)$, then followed by feeling which is 8 
utterances (23.5\%), and then continued by understanding which is 7 utternces $(20.6 \%)$, and then support which is 5 utterances $(14.7 \%)$, and the last is proposal which is 4 utterances (11.8\%). Besides, it can be seen that eventhough Tannen (1992) suggested the orders were categorized for male way's of speaking, but based on this study, orders were found in the female teachers' way of speaking. There were $29.4 \%$ the utterances realized by orders although that criteria is not classified to female. In fact, those way of speaking were the most used in the female teachers. According to the male and female teachers all the ways of communication are expressed to encourage the students to reach the lesson competencies well.

Keywords: English Teachers, Language Styles, Way of communication,

How to Cite: Sinaga, Megawati (2019).

The Realization of Teachers' Language Style with Reference to Sex Difference in Teaching English. Jurnal Linguistik Terapan Pascasarjana Unimed, 16 (3): 518 - 526

${ }^{*}$ Corresponding author: ISSN 0216-5139

megawati21.sinaga71@gmail.com

\section{INTRODUCTION}

Language is essentially a means of communication among the members of a society. It is a medium of teaching, so teachers need to know about the language of our discipline in order to communicate its knowledge and expectations. The teachers' ability to communicate in the classroom which use language as such a key aspect to setting up children for success in their future professional is very important.

Men and women are often said have differences in communication styles. It is in line with Nelson (2007) conclusion about the men and women differences are influenced by the perspective on life they learnt from their childhood that go with them. Dealing with the effect of the language styles use by the teachers in education field, according to Nelson (2007), teaching requires skill, insight, intelligence and diligence in which the faculty struggle and 
succed in a variety of ways to meet the challenges of the classroom. It is in line with a research which has shown that students' evaluation can be significantly influenced by the gender of their teachers.

The difference in the teachers' language style could be as the important factor influence the way to handle teaching learning process especially in English subject. There were some researches about the difference between male and female language style and the findings are various. So beyond understanding how men and women teachers teach differently, it is essential to examine whether and how gender differences (male and female teachers) used the language styles differently.

\section{Problems of the Study}

In order to achieve the valuable input of this study, the research problems are posed below; How are the language styles realized by male and female teachers in teaching English?

\section{Objectives of the Study}

To describe the realization of language styles by male and female teachers in teaching English in the classroom.

Review Literature

Gender refers to the cultural, socially-constructed differencez between the two sexes. It refers to the way a society encourages and teaches the two sexes to behave in different ways through socialisation. Gender refers to differences in behavior and attitudes, and these differences are perceived as a product of the socialisation process rather than of biological appearance. Gender is more appropriate for distinguishing people on the basis of their socio cultural behavior, including speech. Simply, gender is behavioral characteristics.

According to West and Zimmerman in Eckert (2003; 10), gender is not something inherent when someone was born with, and not something which someone has, but something 
which someone does. It means that gender is behavioral characteristics. People show their gender characteristics through something which they do or act, such as the way they interact or communicate with other people. It is also concluded that gender describe what male and female do, how male and female express their thought in doing interaction. Therefore male is believed to be power and status in due to conversation above all when they discuss in public context. Whereas female is believed to be closeness in due to the interaction, they are closeness in discussing the personal problems, so that they talk too much in private than public context.

\section{Six Differences of Male and Female in Communication}

Tannen (1992:32) has postulated six categories, each of which pairs a contrasting use of language by males and females, they are: status versus support, independence versus intimacy, advice versus understanding, information versus feeling, orders versus proposal and conflict versus compromise.

Table 1.1 Male and Female ways of Communication (Tannen (1992: 32)

\begin{tabular}{|l|l|l|}
\hline Male & versus & Female \\
\hline Status & & Support \\
\hline Independence & & Intimacy \\
\hline `Advice & & Understanding \\
\hline Information & & Feeling \\
\hline Order & & Proposal \\
\hline Conflict & & Compromise \\
\hline
\end{tabular}




\section{RESEARCH METHOD}

This research is conducted by using qualitative research. This research is conducted in descriptive case study. It meant that it exposed the real condition of the sources of data and gave detail description in the form of written report based on the real situation, to search how the language styles are performed by male and female teachers in the way they do while teaching English.

The data of this study were taken from the utterances of male and female English teachers which contain two male and two female teachers. The data of this research were the transcription of both recorded observation and interview. This data was analyzed by identifyng and classifying the data by the theory which proposed by Tannen (1992:32) who postulated six categories, each of which pairs a contrasting use of language by males and females, they are: status versus support, independence versus intimacy, advice versus understanding, information versus feeling, orders versus proposal and conflict versus compromise.

Based on the data analysis the percentage of male and female ways of communicating represented as the following;

Table 4.4. The Percentage of Male and Female Ways of Communication

\begin{tabular}{|l|l|l|l|l|l|}
\hline No & Male & $\%$ & Versus & $\%$ & Female \\
\hline 1 & Advice & 32.4 & & 20.6 & Understanding \\
\hline 2 & Information & 20.6 & & 23.5 & Feeling \\
\hline 3 & Conflict & 5.9 & & 0 & Compromise \\
\hline 4 & Status & 2.9 & & 14.7 & Support \\
\hline 5 & Independence & 0 & & 0 & Intimacy \\
\hline 6 & Orders & 38.2 & & 11.8 & Proposals \\
\hline 7 & - & - & & 29.4 & Orders \\
\hline
\end{tabular}


It can be seen obviously in Table 4.4 the realization of language styles by the teachers' way of speaking mostly occur in male teachers' is orders which is 13 utterances (38.2\%), then followed by advice which is 11 utterances (32.4\%), then continued by information 6 utterences $(20,6 \%)$ and then conflict 2 utterances $(5,9 \%)$ and the last is status 1 utterances $(2.9 \%)$. Female teachers' way in communication was mostly realized by orders which is 10 utterances $(29.4 \%)$, then followed by feeling which is 8 utterances $(23.5 \%)$, and then continued by understanding which is 7 utternces (20.6\%), and then support which is 5 utterances (14.7\%), and the last is proposal which is 4 utterances (11.8\%). Besides, it can be seen that eventhough Tannen (1992) suggested the orders were categoried for male way's of speaking, but based on this study, orders were found in the female teachers' way of speaking. There were $29.4 \%$ the utterances realized by orders although that criteria is not classified to female. In fact, those way of speaking were the most used in the female teachers.

Based on Table 4.4 it can be described that:the teachers' language style which realized by :

- advice (male) versus understanding (female) were $32.4 \%: 20.6 \%$

- $\quad$ information (male) versus feeling (female) were $20.6 \%: 23.5 \%$

- conflict (male) versus compromise (female) were 5.9\%:0\%

- $\quad$ status (male) versus support (female) were 2.9\%: $14.7 \%$

- independency (male) versus intimacy (female) were 0\%:0\%

- $\quad$ orders (male) versus proposal (female) were $38.25: 11.8 \%$

- orders which is categorized for male could be used by females' utterances which realized in their way of communicating were $29.4 \%$.

The six categories of ways of communicating which proposed by Tannen (1992:32), which pairs a contrasting use of language by males and females, they are: status versus support, independence versus intimacy, advice versus understanding, information versus 
feeling, orders versus proposal and conflict versus compromise are not found all in the teachers' way of communicating for male an female teachers while teaching English in the classroom. The realization of male and female English teachers' language styles were showed by their ways in communicating.

\section{FINDINGS AND DISCUSSIONS}

1. Tannen (1992: 32) stated that there are six ways of communicating that contrary between male and female. But independency is the male ways of communicating which were not occured in this study, on the other hand, compromise and intimacy are two of female ways of communiacting which were not occured. Orders which should categorized for male way of communicating was realized by female. More over, this realization was highest percentage relized by female English teacher. According to the Tannen's theory, female in their way communicating use proposal rather than order. In fact the percentage of female teachers using order higher than proposal. It means that the female teachers realize their way of communication is contrary to the theory which stated that female use proposal versus order in their ways of communicating.

2. Female teachers used order in their way of communicating rather than proposal because of there are many instructions should be done by the students. It could not be imagined if every time the female teachers give the instructions, they should modify the orders to proposals. Teachers choose the most simple way to instruct their students so the students could understand and obey it directly. The limitation of the time also as one factor to the teacher not using the long instructions while teaching process. Proposals should have an interest, lay the broad foundation, larger context, and reach aout to a specific thing (Pajares, 2017), so it needs longer utterances than order. So, the teachers tend to use order than proposal in their way of communicating. 


\section{CONCLUSIONS}

The ways of communicating of male and female teacher as proposed by Tannen (1992:32) has postulated six categories, each of which pairs a contrasting use of language by males and females. Independency was one criteria which did not realized in male way of communicating, whereas for female were compromise and intimacy. But especially for female, order as male way of communicating was realized too. Moreover orders was the highest percentage realization in teachers way of communicating.

It is suggested to do the further research relate to the factors that influence someone's way communication except gender itself and further research about language styles from different emphasis and to do more explanation and expansion on the theory proposed by other experts related to the current research to avoid the ambiguity. The longer and the detailed research also needed in order to search the the factors among the teachers involved in using the language styles.Especially for the researchers who want study about the language styles deeply, it is suggested to search quantitatively the relation between the teachers' language styles and the achievement of the students in learning English. It is important to check whether the teacher's language styles influence the achievement of the student in studying English.

\section{REFERENCES}

Alderson, J. C., and Lyle, F. Bachman. 2002. Asserting Writing. Cambridge: Cambridge University

Braedyn, S. 2010. The Impact Gender has on Effective Communication. IRWIN Professional Publishing, Burr Ridge,Il

Bogdan, R \& Biklen, S. 1992. Qualitative Research for Education (Second Edition); An Introduction to Theory and Methods. United States of America: Allyn and Bacon

Eckert, P \& John, R.R. 2001. Style and Sociolinguistic Variation. Cambridge: Cambridge University Press 
Halliday, M.A.K 1980. Three Aspects of Children's Language Development: Learning Language, Learning through Language, Learning about Language." Oral and Written Language Development: Impact on Schools. Proceedings from the 1979 and 1980 IMPACT Conferences,ed. Yetta Goodman, Myna Hausser, and Dorothy Strickland. Urbana, IL: International Reading Association and National Council of Teachers of English.

and Jonathan J. Wr. 2005. Computational And Quantitative Studies: The Collected Works Of M.A.K. Halliday. New York: Continuum. pp.28-30.

Harmer,J. 2001. The Practice of English Language Teaching. Cambridge: Longman

Hitchcock, G \& Hughes, D. (2003) Research and the Teacher. A Qualitatitive Introduction to SchoolBased Research. Second Edition. Routledge, New York.Taylor \& Francis Group.

Holmes, J. 1992. An Introduction to Sociolinguistics. New York: Longman 2008. An Introduction to Sociolinguistics. 2nd ed. Harlow: Pearson Education Limited

Hudson, R.A. 1980. Sociolinguitics. Cambridge: Cambridge University Press

Hyland \&Ken (2002). Genre-based pedagogies: A social response to process. In: Journal of Second Language Writing. 12/1. 17-29.

Nelson, T, F. 2007. Gender Gaps: Understanding Teaching Styles Between Men and Women. Retrieved from Association for Institutional Research Journal

Tannen, D. 1990. You Just Don't Understand. Women and Men in Conversation. New York: Willian Morrow. Virago Press

1991. How to Close the Communication Gap between Men and Women. Article from McCall's May, v.118, n.8 